УДК 595.7:57.022:619:616:636.2

\author{
СПОНТАННЫЙ СИМУЛИИДОТОКСИКОЗ \\ КРУПНОГО РОГАТОГО СКОТА В УСЛОВИЯХ \\ ЦЕНТРАЛЬНОЙ НЕЧЕРНОЗЕМНОЙ ЗОНЫ РОССИИ
}

\author{
Василевич Ф. И. ${ }^{1}$, \\ Зиновьева О. Е. ${ }^{1}$,
} Каплич В. М. ${ }^{2}$

\title{
Аннотация
}

Проведены исследования острого течения симулиидотоксикоза молодняка крупного рогатого скота на территории центральной нечерноземной зоны России. Изучены изменения в морфологическом составе крови, иммунной реактивности и естественной резистентности животных при симулиидотоксикозе.

Ключевые слова: мошки, крупный рогатый скот, симулиидотоксикоз, лейкограмма, протеинограмма.

\section{SPONTANEOUS SYMULIDOTOXICOSE OF CATTLE IN CONDITIONS THE CENTRAL NON-CNERNOZEM ZONE OF RUSSIA}

Vasilevich F. I. ${ }^{1}$, Zinovieva O. E. ${ }^{1}$, Kaplich V. M. ${ }^{2}$

\footnotetext{
${ }^{1}$ Федеральное государственное бюджетное образовательное учреждение высшего образования «Московская государственная академия ветеринарной медицины и биотехнологии - МВА имени К.И. Скрябина» (109472, Москва, ул. Академика Скрябина, д. 23)

${ }^{2}$ УО «Белорусский государственный технологический университет» (220006, Минск, ул. Свердлова, 13А), zinovieva_olya@bk.ru

${ }^{1}$ Federal State Budgetary Educational Institution of Higher Education "Moscow state Academy of Veterinary Medicine and Biotechnology - MVA by K.I. Skryabin” (23 Akademika Skryabina, Moscow 109472)

${ }^{2}$ Belarusian State University of Technology (13a Sverdlova, Minsk 220050), zinovieva_olya@bk.ru
} 


\begin{abstract}
Studies have been conducted on the acute course of simulidotoxicosis of young cattle in the territory of the central non-chernozem zone of Russia. The changes in the morphological composition of the blood, immune reactivity and natural resistance of animals with simulidotoxicosis were studied.

Simulids as active bloodsuckers cause a decrease in animal productivity. In addition, they are specific and mechanical carriers of pathogens of a number of animal diseases. In the study area, there are frequent cases of the disease simulidotoxicosis, often ending in the death of animals, especially young cattle.

A comparative analysis has shown that the manifestation of acute simulidotoxicosis is similar in young and adult animals. Blood was examined after 4, 8, 12, 24, 48 and 96 hours to study the morphological and biochemical parameters of the disease. The following cases were registered 4 hours after the onset of the clinical picture with spontaneous simuliotoxicosis: the erythrocytes in the experimental group were lower by $14.6 \%$ compared with the control group. Leukocytes were increased by $47.7 \%$, hemoglobin was decreased by $2.5 \%$. The dynamics of changes after 48 hours after the onset of the disease red blood cells decreased by $36.8 \%$, leukocytes increased by $49.2 \%$, hemoglobin decreased by $52.1 \%$. After 8-24 hours, leukopenia is noted in animals, but after 48 hours the blood profile lines up. There is a decrease in leukocytes, a decrease in total protein and albumin during the entire observation period. When studying leukograms, eosinophilia was noted with an increased content of stab and segmented neutrophils, with a maximum change of 48 hours from the onset of the first symptoms of the disease in animals. Erythropenia with anemia is characteristic of natural simulidotoxicosis at the onset of the disease, and leukopenia is registered on the first 24 hours after the onset of clinical symptoms, which after 48 hours of observation is replaced by leukocytosis.
\end{abstract}

Keywords: midges, cattle, simulidotoxicosis, leukogram, proteinogram.

Введение. На территории центральной нечерноземной зоны России расположена сеть водотоков, которая является основным местом выплода кровососущих мошек. Симулииды как активные кровососы вызывают снижение продуктивности животных. К тому же они являются специфическими и механическими переносчиками возбудителей ряда заболеваний животных. На исследуемой территории нередки случаи заболевания симулиидотоксикозом, часто заканчивающиеся падежом животных, особенно молодняка крупного рогатого скота. В этой связи важны клинико-гематологические исследования симулиидотоксикоза крупного рогатого скота, с целью разработки эффективных способов лечения и профилактики.

Материалы и методы. Острое течение заболевания исследовали на молодняке крупного рогатого скота старше 18 месяцев в мае 2017-2018 гг.

15-17 мая 2019 года, Москва 
В опыте участвовали 9 телок, при этом сформированы 2 группы: 1-ая (5 животных) - опытная, 2-ая группа (4 животных) - контрольная (животные не выгонялись на пастбище вместе со стадом). Для изучения морфологических и биохимических показателей заболевания исследовали кровь через 4, 8, 12, 24, 48 и 96 ч.

Результаты исследований. Сравнительный анализ показал, что проявление острого симулиидотоксикоза сходно у молодняка и взрослого поголовья. Первые клинические симптомы у телок опытной группы отмечаются в 9 ч утра после выгона на пастбище. Основные клинические признаки: отказ от корма во время выпаса, сильное возбуждение, повышенная саливация, множественные точечные кровоизлияния на коже, молодняк машет хвостом, передергивает конечностями, ложится на землю. Отмечается повышение температуры на $1,5-2,0^{\circ} \mathrm{C}$, спустя 4-5 ч зарегистрировано общее угнетенное состояние, повышается пульс и дыхание.

При спонтанном симулиидотоксикозе спустя 4 ч от начала проявления клинической картины зарегистрировано: эритроциты у опытной группы ниже на 14,6\% по сравнению с контрольной группой. Лейкоциты увеличены на 47,7\%, гемоглобин снижен на 2,5\%. Динамика изменений спустя 48 ч после начала заболевания эритроциты снижены на $36,8 \%$, лейкоциты увеличены на 49,2\%, гемоглобин снижен на $52,1 \%$. Спустя 8-24 ч у животных отмечается лейкопения, но спустя 48 ч профиль крови выравнивается. При изучении лейкограммы отмечали эозинофилию с увеличенным содержанием палочкоядерных и сегментоядерных нейтрофилов, с максимальным изменением на 48 ч от начала проявления первых симптомов заболевания у животных. Лимфоциты снижены на протяжении всего времени наблюдения, разница между опытом и контролем на 48 ч составляет $31 \%$. При рассмотрении Т- и В-лимфоцитов было выявлено, что в начале заболевания характерно увеличение Т-лимфоцитов с последующей сменой на В-лимфоциты на 24 ч от момента проявления первых симптомов заболевания. Так В-лимфоциты на 96 ч составляют 46\% по сравнению с контрольной группой. У опытной группы животных на 8 ч после появления клиники заболевания, отмечено снижение общего белка до 38,19 г/л, что составляет 47\% от контрольной группы. При развитии острого заболевания максимальное снижение общего белка отмечается на 24 ч до 31,29 г/л, что составляет $56 \%$ к уровню контрольных животных. На 12 ч проявления симптомов заболевания количество альбумина увеличилось на $21 \%$ в сравнении с контролем. С четкой картиной интоксикации организма наблюдается пониже- 
ние альбуминов на 24 ч, в опытной группе разница составляет $46 \%$ в сравнении с контролем. Зарегистрировано снижение уровня фракции гамма-глобулинов, но спустя 48 ч происходит увеличение их количества на $65 \%$.

Заключение. Исходя из полученных гематологических данных, можно сделать вывод, что для естественного симулиидотоксикоза характерна в начале заболевания эритропения с анемией, в первые сутки после появления клинических симптомов зарегистрирована лейкопения, которая после 48 ч наблюдения сменяется лейкоцитозом. В крови у опытных животных зарегистрирована эозинофилия со сдвигом профиля крови вправо.

\section{Литература}

1. Каплич В.M. Кровососущие мошки (Diptera, Simuliidae) Республики Беларусь: автореф. дис. ... док. биол. наук: 03.00.19 / B.M. Каплич; Ин-т паразитологии РАН. Москва, 1999. 34 с.

2. Скуловец М.В. Симулиидотоксикоз и демодекоз крупного рогатого скота: автореф. дис. ... док. вет. наук: 03.00.19 / В.М. Скуловец; МГАВМиБ имени К.И. Скрябина. Москва, 2005. 38 с.

3. Егоров С.В. Экология кровососущих двукрылых насекомых (Insecta, Diptera: Culicidae, Simuliidae, Tabanidae) и защита животных от них в центральном районе нечерноземной зоны Российской Федерации: автореф. дис. ... док. биол. наук: 03.00.19 / С.В. Егоров: ВНИИГ имени К.И. Скрябина. Москва, 2012. 52 с.

\section{References}

1. Kaplich V.M. Bloodsucking midges (Diptera, Simuliidae) of the Republic of Belarus: Abstract of a thesis. ... doctor of biological sciences: 03.00.19 / V.M. Kaplich; Institute of Parasitology RAS. Moscow, 1999. 34 p. (In Russ.)

2. Skulovets M.V. Simuliidotoksikoz and cattle demodicosis. Abstract of a thesis. ... doctor of vet. sciences: 03.00.19 / V.M. Skulovetc; Moscow state academy of veterinary medicine and biotechnology named K.I. Skryabin. Moscow, 2005. 38 p. (In Russ.)

3. Egorov S.V. Ecology of bloodsucking diptera insects (Insecta, Diptera: Culicidae, Simuliidae, Tabanidae) and the protection of animals in the central region of the nonchernozem zone of the Russian Federation: Abstract of a thesis. ... doctor of biological sciences: 03.00.19 / S.V. Egorov: ARRIHE named K.I. Scriabin. Moscow, 2012. 52 p. (In Russ.) 